\title{
Removal of arsenic and humic substances (HSs) by electro-ultrafiltration (EUF)
}

\author{
Yu-Hsiang Weng ${ }^{\mathrm{a}}$, Lin Han Chaung-Hsieh ${ }^{\mathrm{a}}$, Hsin-Hua Lee ${ }^{\mathrm{a}}$, Kung-Cheh Li ${ }^{\mathrm{a}, *}$, C.P. Huang ${ }^{\mathrm{b}}$ \\ ${ }^{a}$ Graduate Institute of Environmental Engineering, National Taiwan University, Taipei 106, Taiwan, ROC \\ ${ }^{\mathrm{b}}$ Department of Civil and Environmental Engineering, University of Delaware, Newark, DE 19716, USA
}

Received 28 December 2004; received in revised form 29 March 2005; accepted 2 April 2005

Available online 22 April 2005

\begin{abstract}
A laboratory scale electro-ultrafiltration (EUF) system was developed and used to explore the removal of arsenic and humic substances (HSs) from water. As a negatively charged species, arsenate(V) was readily removed after applying voltage to the EUF cell. Arsenite(III) was removed via EUF after the $\mathrm{pH}$ of the water had been adjusted. Meanwhile, the rejection of HSs increased due to the presence of an electric field. This study also showed that the removal of arsenite(III) from water relies primarily on electrostatic and non-electrostatic mechanisms. In the presence of HSs, arsenate(V) complexed with the HSs and was then able to be removed by EUF. This study demonstrates that EUF is a highly promising means of removing arsenic from water.
\end{abstract}

(C) 2005 Elsevier B.V. All rights reserved.

Keywords: Electro-ultrafiltration (EUF); Humic substances (HSs); Arsenate(V); Arsenite(III)

\section{Introduction}

Arsenic-contaminated groundwater has caused serious health problems in numerous countries, such as Bangladesh, India, and Taiwan $[1,2]$. Drinking water that contains arsenic is both chronically carcinogenic and toxic to humans. Recent studies suggest that the current maximum contaminant level (MCL) of $50 \mu \mathrm{g} / \mathrm{L}$ needs to be revised in order to minimize the risk of cancer [3]. Thus, the U.S. Environmental Protection Agency has recently announced that the amount of arsenic allowed to be present in drinking water will be reduced from 50 to $10 \mu \mathrm{g} / \mathrm{L}$ as of January 23, 2006 [4]. In Taiwan, a new limit of $10 \mu \mathrm{g} / \mathrm{L}$ was also introduced in 2003 [5]. Therefore, it is essential to develop technologies that can effectively remove arsenic from water.

The task of removing arsenic from water has received extensive attention. Major approaches include coagulation [6], adsorption [7-10], electrochemical methods [11,12], and

\footnotetext{
* Corresponding author. Tel.: +886 2 23698112; fax: +886223638173.

E-mail address: kcli@ntu.edu.tw (K.-C. Li).
}

membrane separation [13-19]. Of these processes, membrane technology, due to the stringent environmental regulations that must be considered, shows the greatest potential for application in the treatment of drinking water [20,21]. It is generally easier to remove arsenate $(\mathrm{V})$ with the use of membranes than it is to remove arsenite(III), due to the differing charge characteristics of these two species [13,14,16-18]. Brandhuber and Amy [14] have reported that $\mathrm{As}(\mathrm{V})$ can be removed from spiked groundwater with an $8 \mathrm{kDa}$ ultrafiltration (UF) membrane. Interestingly, Donnan exclusion also plays a crucial role during UF of water-containing As(V). In other words, when using membranes to remove arsenic from water, the differing charge characteristics of $\mathrm{As}(\mathrm{V})$ and As(III) is an important factor to be taken into consideration.

At neutral $\mathrm{pH}$, the predominant $\mathrm{As}(\mathrm{V})$ is negatively charged, whereas that of As(III) is neutral. This explains why even the most promising membrane process - reverse osmosis $(\mathrm{RO})$ - is considerably less efficient at removing As(III) from water than it is at removing $\mathrm{As}(\mathrm{V})[13,16]$. Nevertheless, there are still two strategies that can be used to tackle this problem-elevating the $\mathrm{pH}$ of water-containing As(III) or oxidizing $\mathrm{As}(\mathrm{III})$ to $\mathrm{As}(\mathrm{V})[16,20,22]$. 
Ubiquitous in groundwater and surface water, humic substances (HSs) are the precursors of carcinogenic disinfection by-products (DBPs) during chlorination of finished water. The production of DBPs, such as trihalomethanes (THMs) and halo acetic acids (HAAs), is a public health concern. The membrane process has shown the potential to control the amount of HSs in drinking water [21].

Both arsenic and HSs are negatively charged at neutral $\mathrm{pH}$ and it is important to note that HSs cannot be removed from water by electrochemical methods. Therefore, there is an interest in improving the performance of UF through the application of an electrical force, in order to attract these charged species. Applying an electric field through the membrane during membrane filtration is known as 'electrofiltration' [23]. In this process, the imposed electric field is parallel to the pressure gradient applied to the membrane. Although it has been reported that the removal of HSs was more successful after voltages were applied through UF [24], it is still not known whether it is possible to remove arsenic and HSs simultaneously by electro-ultrafiltration (EUF).

In this study, a laboratory-sized EUF unit was employed to remove arsenic and HSs from water. Total arsenic concentration and dissolved organic matter (DOC) were used as water quality indicators. In addition to evaluating the performance of EUF during treatment of water-containing arsenic and HSs, this study focused on understanding the removal mechanisms more thoroughly.

\section{Materials and methods}

\subsection{Feed solution}

Sodium arsenite $\left(\mathrm{NaAsO}_{2}\right)$ and arsenate oxide $\left(\mathrm{As}_{2} \mathrm{O}_{5} \cdot \mathrm{XH}_{2} \mathrm{O}\right.$ ) (supplied by Sigma-Aldrich) were used in preparing $\mathrm{As}(\mathrm{III})$ and $\mathrm{As}(\mathrm{V})$ solutions. These two arsenic oxidation states are common in natural water. The powdered arsenic was dissolved in Mill-Q water and diluted to $20-40 \mu \mathrm{g} / \mathrm{L}$ prior to use.

The HSs solution was prepared by dissolving powdered humic acid (Aldrich), which was then filtered through a $0.45 \mu \mathrm{m}$ filter, in order to represent dissolved organic matters in water. The concentration of dissolved organic carbon in the feed water was approximately $4 \mathrm{mg} / \mathrm{L}$. For most of the experiments, the $\mathrm{pH}$ was not adjusted $(\sim 6)$. Sodium hydroxide was only used to adjust the $\mathrm{pH}$ of the solution in particular circumstances.

\subsection{Membranes and module}

Osmonic $100 \mathrm{kDa}$ UF membranes were used in this study. These membranes are made of polyacrylonitrile (PAN) and are hydrophilic on the surface. Table 1 lists the typical characteristics of these membranes. A new membrane was used for each experiment. Fig. 1 shows the schematic drawing of the EUF module. The filtration module comprises of plastic
Table 1

Characteristics of UF membrane $\mathrm{a}^{\mathrm{a}}$

\begin{tabular}{ll}
\hline Characteristics & Value \\
\hline Size $(\mathrm{kDa})$ & 100 \\
Contact angle & $4^{\circ}$ \\
Operating pH range & $2-10$ \\
Typical operating pressure $(\mathrm{kPa})$ & $98-400$ \\
Maximum temperature $\left({ }^{\circ} \mathrm{C}\right)$ & 50 \\
Filtration area $\left(\mathrm{m}^{2}\right)$ & 14.7 \\
Material & Polyacrylonitrile (PAN) \\
\hline
\end{tabular}

${ }^{\text {a }}$ Data were obtained from catalog of the manufacturer.

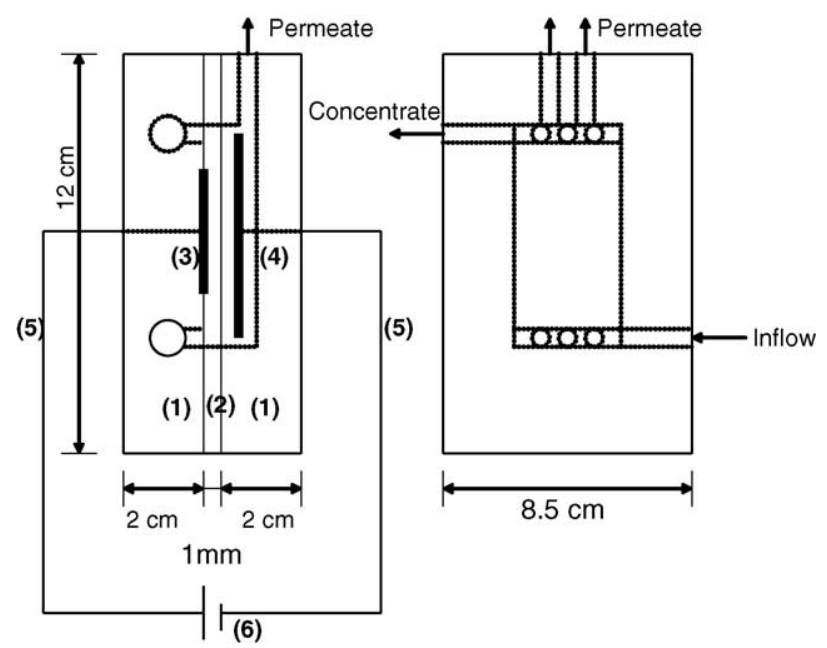

Fig. 1. Electro-ultrafiltration (EUF) module. (1) Plastic plate, (2) silicon lining, (3) anode: (+), (4) cathode: (-), (5) wire, and (6) power supply.

plates, silicon lining, and electrodes, and the module measures $8.5 \mathrm{~cm}$ in length, $2.3 \mathrm{~cm}$ in width, and $12 \mathrm{~cm}$ in height. The silicon lining between the plates creates a filtration channel $1 \mathrm{~mm}$ wide. Since the HSs are negatively charged, the anode (positively charged) is placed on the feed side (concentrate side) to attract the pollutants. The anode is platinum and the cathode is titanium. The distance between the electrodes is about $4 \mathrm{~mm}$.

\subsection{Filtration experiment}

Fig. 2 demonstrates the operational mode of the experiments. Five litres of arsenic solutions, with and without HSs, were prepared as the feed water for each experiment. A power

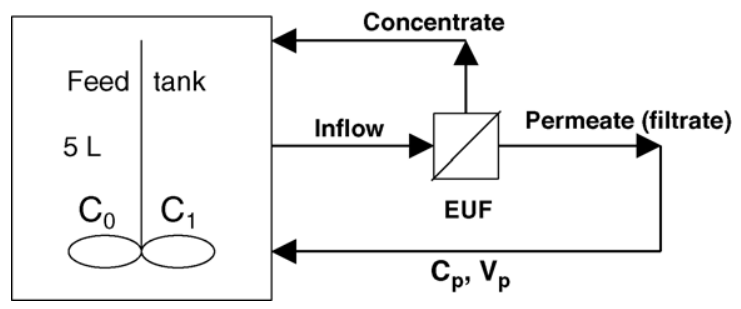

Fig. 2. Operational mode of a laboratory scale EUF system. $C_{0}$ : initial concentration, $C_{1}$ : concentration after experiment, $C_{\mathrm{p}}$ : concentration in permeate stream, and $V_{\mathrm{p}}$ : amount of permeate passing cathode. 
supply (Chroma, Model 6210K-600) was utilized to provide electrical voltage through the membrane. Before each experiment, the membrane was soaked for $1 \mathrm{~h}$ in, and then flushed for $1 \mathrm{~h}$ with, deionized water, in order to remove any impurities and preservatives. A peristaltic pump conveyed solutions into the EUF cell with an averaged crossflow velocity of $0.1 \mathrm{~m} / \mathrm{s}$. Pressure was kept at $98 \mathrm{kPa}$ with a back regulator. The amount of permeate passing through the membrane was determined with an electric balance (Satorius). Data were then transferred to a personal computer via RS232. Both concentrate and permeate streams were recycled back into the tank and samples were taken before and after each experiment for the analysis of total arsenic and organic concentrations.

\subsection{Chemical analysis}

DOC was analyzed with an OI Analytical 1010 and measurement of $\mathrm{pH}$ was carried out with a Consort $\mathrm{C} 831 \mathrm{pH}$ meter. Conductivity was measured with a Suntex SC-120 conductivity meter.

Total arsenic concentration was analyzed with a PerkinElmer Analyst 800. The experiment procedures followed standard methods [25]. As(V) was reduced to As(III) by adding concentrated trace metal $\mathrm{HCl}$ and $\mathrm{KI}(20 \%$, w/v). After $1 \mathrm{~h}$ of reaction time, arsine gas was generated by continuous addition of $\mathrm{NaBH}_{4}$. Absorbance of arsine at $193.7 \mathrm{~nm}$ was recorded as peak high.

\section{Results and discussion}

\subsection{As(III) and $A s(V)$ removal efficiency}

The rejection of arsenic $\left(R_{\mathrm{f}}\right)$, with and without HSs, was calculated using Eq. (1).

$R_{\mathrm{f}}=\left(1-\frac{C_{\mathrm{p}}}{C_{0}}\right) \times 100 \%$

In this equation, $C_{\mathrm{p}}$ is the arsenic concentration in the permeate and $C_{0}$ is the initial arsenic concentration. The total arsenic measurement follows the method described in Section 2.4.

The results of the experiment proved that applying voltages through the membrane enhanced the removal of $\mathrm{As}(\mathrm{V})$ (Fig. 3a). Arsenic rejection increased from 30\% to more than $90 \%$ after applying voltages. At neutral $\mathrm{pH}, \mathrm{As}(\mathrm{V})$ exists in water as the negative ion $\mathrm{HAsO}_{4}{ }^{-}$. The surface charge of the PAN membrane is also negative at neutral $\mathrm{pH}$. Thus, it was possible to repel the negatively charged $\mathrm{As}(\mathrm{V})$ ions by Donnan exclusion. However, since the pores on the membrane are much larger than the $\mathrm{As}(\mathrm{V})$ ions, Donnan exclusion was not as pronounced as that in nanofiltration, in which more than $90 \%$ of $\mathrm{As}(\mathrm{V})$ was removed [13]. During traditional UF, the differing $\mathrm{As}(\mathrm{V})$ rejection rates in water with and without HSs may be due to the formation of an As-HSs complex, which is retained easier than $\mathrm{As}(\mathrm{V})$ alone. The improvements in $\mathrm{As}(\mathrm{V})$
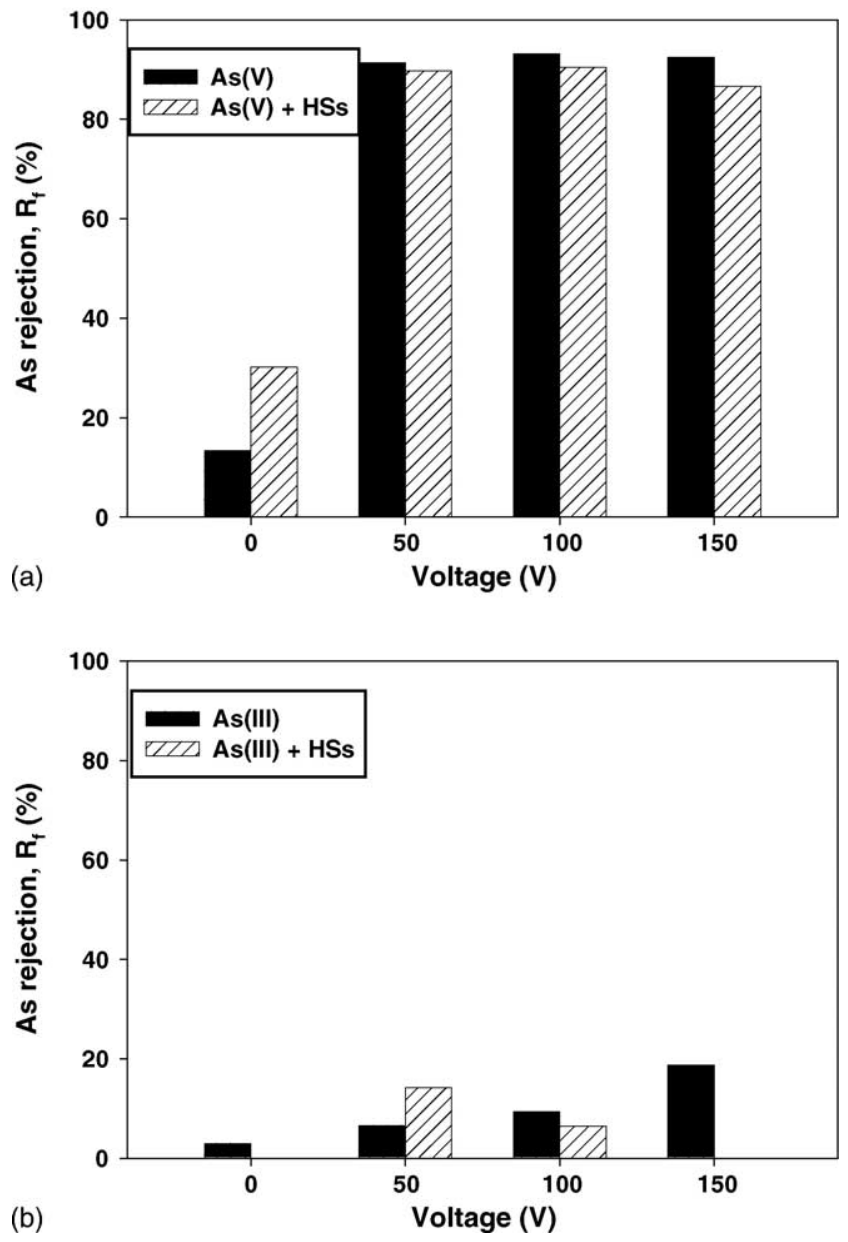

Fig. 3. Removal of synthetic (a) As(V) and (b) As(III) from water by EUF at different voltages $(\mathrm{pH} \sim 6)$.

removal efficiency after voltages had been applied may result from the external electrical field which may have kept $\mathrm{As}(\mathrm{V})$ in the concentrate side, or led to a reduction reaction occurring at the cathode.

In contrast, As(III) rejection was quite low, even with the addition of electrical voltages (Fig. 3b). Applying an electrical charge through a membrane did not increase the As(III) removal efficiency either in the presence or absence of HSs as, since $\mathrm{As}(\mathrm{III})$ is nonionic at a neutral $\mathrm{pH}$, it was not influenced by the electrical field. On the other hand, it was easier to remove $\mathrm{As}(\mathrm{V})$ due to its negativity. Electrochemical reduction studies on arsenic reduction have showed that it is easier to reduce $\mathrm{As}(\mathrm{III})$ than $\mathrm{As}(\mathrm{V})[12,26]$. Thus, it was not anticipated that electrochemical reduction would play an important role in the EUF of arsenic, due to its low conductivity $(\sim 7 \mu \mathrm{S} / \mathrm{cm})$, low current $(\sim 4 \mathrm{~mA})$ and various cathode materials.

Nonetheless, there are two methods of increasing the removal of As(III) that look promising [16,20,22]. The first involves the oxidation of $\mathrm{As}(\mathrm{III})$ to $\mathrm{As}(\mathrm{V})$, whilst the second method raises the $\mathrm{pH}$ of water, causing protons to dissociate, and thus leaving As(III) negatively charged. Since it is pos- 


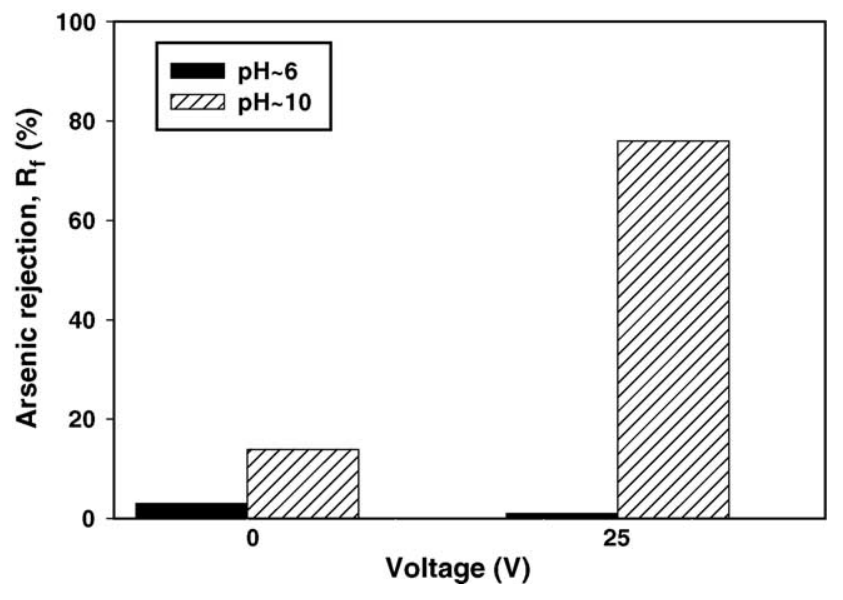

Fig. 4. Removal of As(III) by EUF via $\mathrm{pH}$ adjustment $(\mathrm{pH} \sim 10)$.

sible to remove $\operatorname{As}(\mathrm{V})$ with EUF as previously indicated, the second option of increasing $\mathrm{pH}$ value was explored.

Fig. 4 shows the removal of As(III), with and without electrical voltage, and before and after $\mathrm{pH}$ adjustment. It is obvious that, without $\mathrm{pH}$ adjustment or electrical voltage, the UF membrane would only be able to remove a minimal amount of As(III). However, after adjusting the $\mathrm{pH}$ of the water to $\sim 10$ and applying a $25 \mathrm{~V}$ charge through the membrane, As(III) removal efficiency increased from 14 to $76 \%$. After $\mathrm{pH}$ adjustment, the solution conductivity increased, thus signifying a decrease of resistance. It should be noted that, at high solution conductivity, the current increased dramatically as voltage was increased. Therefore, in order to reduce the joule heating and the hydrolysis rate of the water, voltage was only raised to $25 \mathrm{~V}$. The removal mechanisms for As(III) after $\mathrm{pH}$ adjustment might be similar to that for $\mathrm{As}(\mathrm{V})$, with the exception of the oxidation of As(III) at the anode. Oxidization of $\mathrm{As}(\mathrm{III})$ to $\mathrm{As}(\mathrm{V})$ could facilitate the removal of As(III) by EUF. The increment of arsenic rejection after $\mathrm{pH}$ adjustment in traditional UF has also been reported in various studies [14,16-18].

\subsection{Removal mechanism}

The increased arsenic removal efficiency that occurred after applying voltages could be a result of external field separation (electrophoresis), cathodic reduction and/or adsorption on membrane pores. Since both the concentration and permeate were recycled back to the feed tank (Fig. 2), the total arsenic concentration before and after the experiment would only be the same as that at the beginning of the experiment if the electrical separation had occurred. Table 2 summarizes the changes in the total arsenic concentrations before and after the experiments under three test conditions, i.e., $\mathrm{As}(\mathrm{III})$ at $\mathrm{pH} \sim 10, \mathrm{As}(\mathrm{V})$ at $\mathrm{pH} \sim 6$, and $\mathrm{As}(\mathrm{V})$ with $\mathrm{HSs}$ at $\mathrm{pH} \sim 6$. The overall arsenic removal efficiency ranges from 71 to $100 \%$. Surprisingly, as is shown in column 3 of Table 2, the concentration of both $\mathrm{As}(\mathrm{III})$ and $\mathrm{As}(\mathrm{V})$ was less at the end of the experiment than at the start. A simple calculation,
Eq. (2), was used in order to account for this loss of arsenic.

$C_{1} \times V_{0}=C_{0} \times\left(V_{0}-V_{\mathrm{p}}\right)+C_{\mathrm{ave}} \times V_{\mathrm{p}}$

In Eq. (2), the water after the experiments is treated as consisting of two separate volumes. First, there is the volume of water $\left(V_{0}-V_{\mathrm{p}}\right)$ containing the original arsenic concentration $\left(C_{0}\right)$. And second, there is the volume of water passing through the cathodic chamber $\left(V_{\mathrm{p}}\right)$, which has an averaged arsenic concentration $\left(C_{\text {ave }}\right)$. The volume of permeate passing through the cathode $\left(V_{\mathrm{p}}\right)$ can be obtained by integrating a flux curve with time.

Notably, $C_{\text {ave }}$ could be regarded as the part of the arsenic compound that can be recovered with EUF. If $C_{\text {ave }}$ were equal to $C_{0}$, i.e., if $C_{1}$ were equal to $C_{0}$, then EUF would not lose arsenic ions and thus physical separation would occur. Conversely, if $C_{\text {ave }}$ were markedly different from $C_{0}$, then EUF would lose arsenic ions as a result of either adsorption or deposition on the cathode. Therefore, the difference between $C_{0}$ and $C_{\text {ave }}$ was adopted as the amount of arsenic lost due to non-electrostatic interaction, whereas the difference between $C_{\text {ave }}$ and $C_{\mathrm{p}}$ came from electrostatic interaction. It should be noted that, if arsenic is removed either by electrostatic or non-electrostatic reactions, $C_{\mathrm{p}}$ will always be lower than $C_{\text {ave }}$. Moreover, the unknown $C_{\text {ave }}$ can be obtained by using Eq. (2).

For condition (I), as displayed in Table 2, the initial As(III) concentration of $40.2 \mu \mathrm{g} / \mathrm{L}\left(C_{0}\right)$ reduced to a final value of $11.5 \mu \mathrm{g} / \mathrm{L}\left(C_{\mathrm{p}}\right)$. The averaged arsenic concentration of permeate $\left(C_{\text {ave }}\right)$ of $25.3 \mu \mathrm{g} / \mathrm{L}$ can be computed from Eq. (2). The experiment data in Table 2 also indicate that both external electrical separation and cathodic reduction could be the key mechanisms during EUF of As(III) water under high $\mathrm{pH}$. Different mechanisms must be used for the removal of $\operatorname{As}(\mathrm{V})$, depending on whether HSs are present or not. For test condition (II), the averaged arsenic concentration $\left(C_{\text {ave }}\right)$ of $3.7 \mu \mathrm{g} / \mathrm{L}$ was slightly greater than the arsenic concentration in permeate $\left(C_{\mathrm{p}}\right)(2.4 \mu \mathrm{g} / \mathrm{L})$ at the end of experiment. A possible reason for this might be that $\mathrm{As}(\mathrm{V})$ was reduced and deposited on the cathode during the experiment. Another explanation might be that $\mathrm{As}(\mathrm{V})$ was adsorbed on the membrane, thus resulting in the loss of $\mathrm{As}(\mathrm{V})$ after the experiment. In contrast, there was little arsenic loss in condition (III), with a $C_{0}$ of $19.5 \mu \mathrm{g} / \mathrm{L}$ and a $C_{\text {ave }}$ of $18 \mu \mathrm{g} / \mathrm{L}$, as shown in Table 2 . The $C_{\text {ave }}$ was higher in condition (III) than in condition (II) because in condition (II) As(V) complexed with HSs, thus eliminating the potential of an $\mathrm{As}(\mathrm{V})$ reduction reaction in the cathode.

Fig. 5 summarizes the results of the laboratory work. For condition (I), both electrostatic and non-electrostatic removals were important. For condition (II), non-electrostatic removal, such as arsenic reduction at the cathode and adsorption on the membrane, dominated the reaction. On the other hand, electrostatic removal, i.e., electrophoresis, was the major removal mechanism in condition (III). The results of this study demonstrated that non-electrostatic separation 
Table 2

Experimental data and calculation of averaged As concentration $\left(C_{\text {ave }}\right)$ passing through membrane

\begin{tabular}{|c|c|c|c|c|c|c|c|}
\hline Test condition* & $\begin{array}{l}\text { Initial As } \\
\text { concentration } \\
(\mu \mathrm{g} / \mathrm{L}) C_{0}\end{array}$ & $\begin{array}{l}\text { As concentration } \\
\text { after filtration } \\
(\mu \mathrm{g} / \mathrm{L}) C_{1}\end{array}$ & $\begin{array}{l}\text { Volume of } \\
\text { water in feed } \\
\operatorname{tank}(\mathrm{mL}) V_{0}\end{array}$ & $\begin{array}{l}\text { Amount of } \\
\text { permeate passing } \\
\text { cathode }(\mathrm{mL}) V_{\mathrm{p}}\end{array}$ & $\begin{array}{l}\text { As concentration in } \\
\text { permeate at end of } \\
\text { experiments }(\mu \mathrm{g} / \mathrm{L}) C_{\mathrm{p}}\end{array}$ & $\begin{array}{l}\text { As removal } \\
\text { efficiency } R_{\mathrm{f}} \\
(\%)\end{array}$ & $\begin{array}{l}\text { Averaged As } \\
\text { concentration in permeate } \\
(\mu \mathrm{g} / \mathrm{L}) C_{\mathrm{ave}}{ }^{* *}\end{array}$ \\
\hline (I) & 40.2 & 37.2 & 4950 & 991 & 11.5 & 71 & 25.3 \\
\hline (II) & 24.8 & 20.5 & 4950 & 1004 & 2.4 & 90 & 3.7 \\
\hline (III) & 19.5 & 19.2 & 4950 & 1096 & N.D. & 100 & 18.0 \\
\hline
\end{tabular}

* (I) As(III) with an initial $\mathrm{pH} \sim 10$ at $25 \mathrm{~V}$; (II) As(V) with an initial $\mathrm{pH} \sim 6$ at $150 \mathrm{~V}$; (III) As(V) + HSs with an initial $\mathrm{pH} \sim 6$ at $150 \mathrm{~V}$.

** $C_{\text {ave }}$ was obtained from Eq. (2).

for As(V) might be more significant than that for As(III). In the past, it has generally been considered that electrochemical reduction of $\mathrm{As}(\mathrm{III})$ has been more active than that of $\mathrm{As}(\mathrm{V})$ [12]. The major differences between this study and previous studies lie in the use of different cathode materials and ionic strength of the solution. Notably, cathode material influences the deposition rate of arsenic [26].

\subsection{Flux and HSs removal efficiency}

Fig. 6a shows the final flux versus voltages plot. The incremental flux during EUF is similar to that in results obtained from studies on the electrofiltration of proteins, bacteria, and colloids [24,27-29]. The incremental flux during EUF was attributed to electrophoresis, which carried foulants away from the membrane, and to electroosmosis phenomenon-the complement of electrophoresis [30]. Flux declination was not significant during the traditional UF ex-
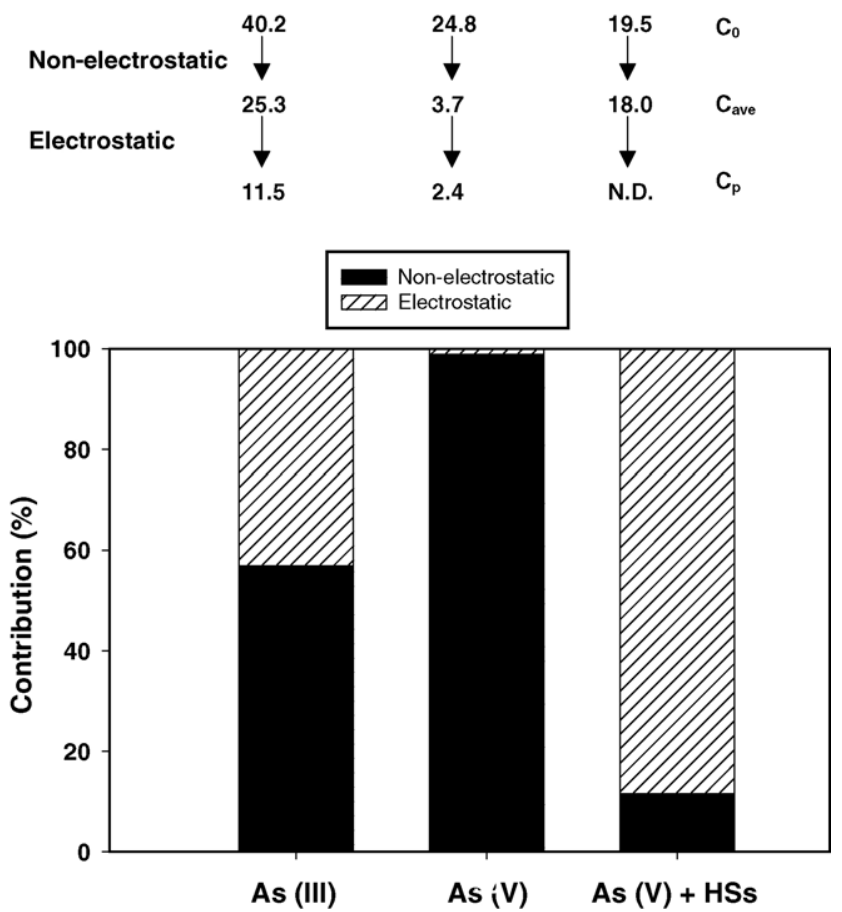

Fig. 5. Preliminary removal mechanisms. (I) As(III) with initial $\mathrm{pH}$ of $\sim 10$, at $25 \mathrm{~V}$ and $71 \%$ total As removal after experiment. (II) As(V) with initial $\mathrm{pH}$ of $\sim 6$, at $150 \mathrm{~V}$ and $90 \%$ total As removal after experiment. (III) As(V) + HSs with initial $\mathrm{pH}$ of $\sim 6$, at $150 \mathrm{~V}$ and $100 \%$ total As removal after experiment. periment. Electrophoresis, which refers to the motion of particles influenced by an electrical field, could not thoroughly explain the flux incremental. Therefore, it was anticipated that electroosmosis, in combination with electrophoresis, resulted in an incremental flux.

The HSs removal efficiency increased after applying electricity through the membrane (Fig. 6b). The enhanced removal rate occurred due to the fact that the applied external electrical field counterbalanced the convective movement of negatively charged HSs toward the membrane [23]. More than $98 \%$ of HSs removal from water was
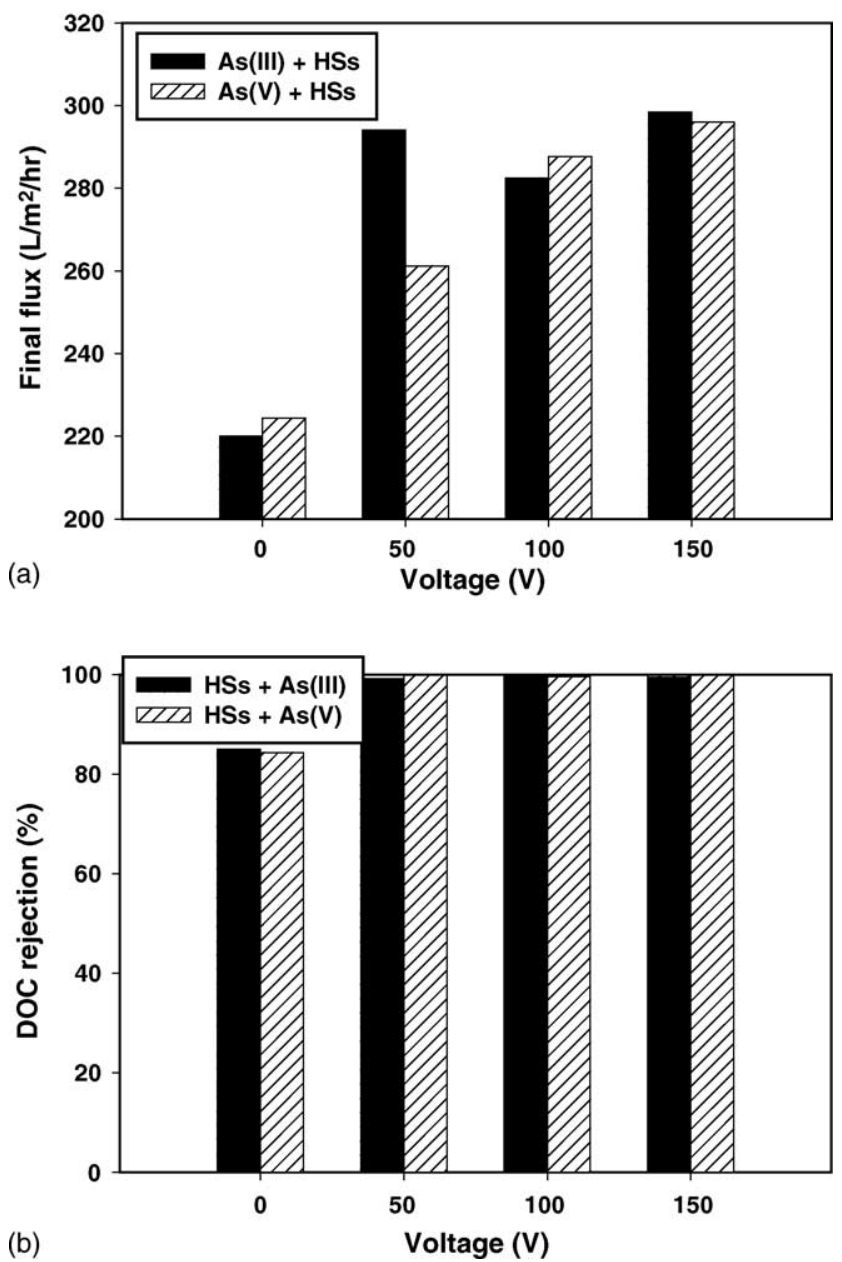

Fig. 6. Flux and DOC results: (a) final permeate flux and (b) water quality analysis of synthetic water at different voltage. 
achieved by applying $25 \mathrm{~V}$, which corresponds to an electrical field of $41 \mathrm{~V} / \mathrm{cm}\left(I=0.004 \mathrm{~A}\right.$, area $=14.7 \mathrm{~cm}^{2}$, conductivity $\left.=6.7 \times 10^{-6} \mathrm{~S} / \mathrm{cm}\right)$. A theoretical field strength $\left(E_{\text {critical }}\right)$ that could retain all charged particles was calculated at $24 \mathrm{~V} / \mathrm{cm}$ by using Eq. (3), where $J(\mathrm{~cm} / \mathrm{s})$ is the filtration flux and $u_{\mathrm{p}}\left(\mathrm{cm}^{2} /(\mathrm{V} \mathrm{s})\right)$ is the electophoretic mobility of charged species.

$E_{\text {critical }}=\frac{J}{u_{\mathrm{p}}}$

The averaged filtration flux in this study was approximately $7.2 \times 10^{-3} \mathrm{~cm} / \mathrm{s}$. HSs have an electrophoretic mobility of $3.0 \times 10^{-4} \mathrm{~cm}^{2} /(\mathrm{V} \mathrm{s})$ [24]. When the applied electrical field approaches the theoretical $E_{\text {critical }}$ value of $24 \mathrm{~V} / \mathrm{cm}$, the removal of HSs from water can be expected. Other studies have also reported similar improvements when the solute size was smaller than the pores on the membrane [24,28].

\section{Conclusion}

Based on the authors' knowledge, this study is the first in which EUF was used to treat water-containing arsenic. The traditional $100 \mathrm{kDa}$ UF membrane is unable to remove As(III) or $\mathrm{As}(\mathrm{V})$ from water, regardless of whether HSs are present or not. After applying electricity to UF, As(V) rejection increased dramatically. The removal mechanisms adopted for $\mathrm{As}(\mathrm{V})$ were electrophoretic force and electrochemical reduction, depending on whether $\mathrm{As}(\mathrm{V})$ had complexed with HSs. Additionally, the removal of As(III) with EUF was achieved via $\mathrm{pH}$ adjustment. In short, both non-electrostatic and electrostatic separation of arsenic are important steps during EUF treatment of water-containing arsenic. The results of these experiments showed that there is significant potential in applying EUF to treat water, which contains arsenic and HSs.

\section{Acknowledgement}

This work was partly supported by the National Science Council of the Republic of China.

\section{References}

[1] M. Karim, Arsenic in groundwater and health problems in Bangladesh, Water Res. 34 (2000) 304-310.

[2] S. Chen, S. Dzeng, M. Yang, K. Chiu, G. Shieh, C. Wai, Arsenic species in groundwaters of the blackfoot disease area, Taiwan, Environ. Sci. Technol. 28 (1994) 877-881.

[3] National Research Council, Arsenic in Drinking Water: 2001 Update, National Academy Press, Washington, http://www.nap.edu, 2001.

[4] EPA, USA, http://www.epa.gov/ogwdw.

[5] EPA, ROC, http://www.epa.gov.tw/main/index.asp.

[6] J. Hering, P. Chen, J. Wilkie, M. Elimelech, Arsenic removal from drinking water during coagulation, J. Environ. Eng.-ASCE 123 (1997) 800-807.

[7] S. Chakravarty, V. Dureja, G. Bhattacharyya, S. Maity, S. Bhattacharjee, Removal of arsenic from groundwater using low cost ferruginous manganese ore, Water Res. 36 (2002) 625632.

[8] M. DeMarco, A. Sengupta, J. Greenleaf, Arsenic removal using a polymeric/inorganic hybrid sorbent, Water Res. 37 (2003) 164-176.

[9] O. Thirunavukkarasu, T. Viraraghavan, K. Subramanian, Arsenic removal from drinking water using iron oxide-coated sand, Water Air Soil Pollut. 142 (2003) 95-111.

[10] R. Vaishya, S. Gupta, Arsenic removal from groundwater by iron impregnated sand, J. Environ. Eng.-ASCE 129 (2003) 89-92.

[11] M. Arienzo, P. Adamo, J. Chiarenzelli, M. Bianco, A. De Martino, Retention of arsenic on hydrous ferric oxides generated by electrochemical peroxidation, Chemosphere 48 (2002) 1009-1018.

[12] D. Bejan, N. Bunce, Electrochemical reduction of As(III) and As(V) in acidic and basic solutions, J. Appl. Electrochem. 33 (2003) 483-489.

[13] P. Brandhuber, G. Amy, Alternative methods for membrane filtration of arsenic from drinking water, Desalination 117 (1998) 1-10.

[14] P. Brandhuber, G. Amy, Arsenic removal by a charged ultrafiltration membrane-influences of membrane operating conditions and water quality on arsenic rejection, Desalination 140 (2001) 1-14.

[15] B. Han, T. Runnells, J. Zimbron, R. Wickramasinghe, Arsenic removal from drinking water by flocculation and microfiltration, Desalination 145 (2002) 293-298.

[16] M. Kang, M. Kawasaki, S. Tamada, T. Kamei, Y. Magara, Effect of $\mathrm{pH}$ on the removal of arsenic and antimony using reverse osmosis membranes, Desalination 131 (2000) 293-298.

[17] T. Urase, J. Oh, K. Yamamoto, Effect of $\mathrm{pH}$ on rejection of different species of arsenic by nanofiltration, Desalination 117 (1998) 11-18.

[18] E. Vrijenhoek, J. Waypa, Arsenic removal from drinking water by a "loose" nanofiltration membrane, Desalination 130 (2000) 265-277.

[19] J. Waypa, M. Elimelech, J. Hering, Arsenic removal by RO and NF membranes, J. Am. Water Works Assess. 89 (1997) 102-114.

[20] M. Bissen, F. Frimmel, Arsenic - a review. Part II: oxidation of arsenic and its removal in water treatment, Acta Hydroch. Hydrob. 31 (2003) 97-107.

[21] B. Van der Bruggen, C. Vandecasteele, Removal of pollutants from surface water and groundwater by nanofiltration: overview of possible applications in the drinking water industry, Environ. Pollut. 122 (2003) 435-445.

[22] J. Jiang, Removing arsenic from groundwater for the developing world-a review, Water Sci. Technol. 44 (2001) 89-98.

[23] H. Huotari, G. Tragardh, I. Huisman, Crossflow membrane filtration enhanced by an external DC electric field: a review, Chem. Eng. Res. Des. 77 (1999) 461-468.

[24] Y.-H. Weng, K.-C. Li, Electrically enhanced crossflow ultrafiltration for treatment of water containing humic acid: a preliminary study, Adv. Asian Environ. Eng. 3 (2003) 60-66.

[25] The American Public Health Association and the Water Environment Federation, Method 3314, Arsenic and Selenium by Hydride Generation/Atomic Absorption Spectrometry, in: L. Clesceri, A. Greenberg, A. Eaton (Eds.), Standard Methods for the Examination of Water and Wastewater, 20th ed., APHA, Washington, DC, 1998, pp. 3.32-3.37.

[26] I. Chernykh, A. Tomilov, A. Smetanin, A. Khudenko, Electrochemical reduction of arsenic acid, Russ. J. Electrochem. 37 (2001) 942-946.

[27] S. Oussedik, D. Belhocine, H. Grib, H. Lounici, D. Piron, N. Mameri, Enhanced ultrafiltration of bovine serum albumin with pulsed electric field and fluidized activated alumina, Desalination 127 (2000) 59-68.

[28] R. Wakeman, Electrically enhanced microfiltration of albumin suspensions, Food Bioprod. Process. 76 (1998) 53-59.

[29] C. Chuang, C. Fang, K. Tung, Electro-microfiltration of colloidal suspensions, Sep. Sci. Technol. 38 (2003) 797-816.

[30] P. Hiemenz, R. Rajagopalan, Electrophoresis and other electrokinetic phenomena. Principles of Colloid and Surface Chemistry, third ed., Marcel Dekker Inc., New York, 1997, pp. 534-570. 